\title{
Bogaty język, zaniedbany język - refleksje o kulturze języka
}

Streszczenie: Artykuł Bogaty język, zaniedbany język - refleksje o kulturze języ$k a$ dotyczy wybranych zjawisk językowych. W centrum uwagi znajdują się leksykalne i ortograficzne oraz składniowe i interpunkcyjne zaniedbania dostrzegane w komunikatach tworzonych przez instytucje państwowe. Materiał analityczny pochodzi m.in. ze sprawozdania Rady Języka Polskiego za lata 2010-2011, które dotyczy oficjalnej komunikacji instytucji państwowych z Polakami. Celem opisu jest wskazanie przyczyn wybranych błędów oraz prezentacja zasad regulujących pisownię prawidłową, a także przedstawienie skorygowanych wersji omawianych przykładów. Wnioski płynące z analizy oficjalnych dokumentów pod kątem przestrzegania kultury języka przekładają się na refleksję dotyczącą odpowiedzialności za kondycję języka polskiego, który jest ważnym składnikiem tożsamości narodowej.

Słowa kluczowe: kultura języka polskiego (składnia, leksyka, ortografia, interpunkcja, błąd językowy), kondycja języka, Rada Języka Polskiego, sprawozdanie

Moment jest szczególny, bo w sferze języka zachodza pospieszne i głębokie zmiany. Pod wptywem kultury masowej, a zwtaszcza powszechnego już dostępu do Internetu, kształtują się nowe normy i formy używania języka. Odrębne dotąd strumienie komunikacji - mowa, pismo, obraz, znak, gest - mieszaja się, tacza w jedna rwaca rzekę. Przetamywane sa bariery między językami, nie tylko wskutek upowszechnienia angielszczyzny jako języka światowego, ale także dzięki coraz doskonalszym systemom maszynowych ttumaczeń; tradycyjne reguty poprawności ustępuja wymogom sprawności; intensywność komunikacji powoduje jej uproszczenie, aż do poziomu wulgaryzacji; języki rozwijaja się w zawodowych $i$ środowiskowych niszach, a jednocześnie ubożeja jako spoiwo catej językowej wspólnoty. Agnieszka Krzemińska, Jerzy Baczyński i Leszek Będkowski (2012, s. 3) 


\section{Ustalenia terminologiczne i cel pracy}

W tytule publikacji użyłam dwóch przydawek - bogaty oraz zaniedbany. Przenośne znaczenia tych wyrazów odnoszę do autotelicznej wartości, jaką jest język. Celowo nie używam w tytule i w tekście antonimów bogaty - ubogi. O ile pierwsze słowo jest obecne w metaforze mieć bogaty język (lub mieć ubogi język1 ), która znaczy „mieć większy niż przeciętny zasób słownictwa oraz doskonale znać formy gramatyczne i sprawnie się nimi posługiwać", o tyle drugie (ubogi) jest bardzo pojemne semantycznie i nazywa zjawiska, które nie znajdują funkcjonalnego uzasadnienia w języku. Wychodzę bowiem z założenia, że język jest bogaty, ale uzus nie zawsze pozwala na eksponowanie tej wartości, stąd stosowana przeze mnie opozycja bogaty język - zaniedbany język. Wskazane kontrapunkty mogą stanowić kontinuum, ponieważ dostrzeganie uchybień językowych (zaniedbań językowych) warto traktować jako przejaw troski o kondycję języka - jego estetykę i autonomię (bogactwo języka).

Celem artykułu jest zwrócenie uwagi na wybrane zjawiska językowe, które są ekspansywne w polskojęzycznej przestrzeni komunikacyjnej w XXI wieku. Nie sposób poruszyć w tekście, jakim jest typowy artykuł, zbyt wielu wątków, dlatego swoją analizę zawężam do wybranych kwestii opisanych: 1) w sprawozdaniach tworzonych przez Radę Języka Polskiego ${ }^{2}$ (dalej stosuję skrót

1 Jako przykład ubogiego języka można podać idiolekt Helutki Szczukinej - bohaterki powieści satyrycznej Dwanaście krzeset (Ilf i Pietrow, 1991), która operuje trzydziestoma odpowiednio intonowanymi powiedzonkami i wykrzyknikami, wyselekcjonowanymi z bogatego języka. Są to np.: 1) nie wygtupiaj się oraz coś podobnego frazy te wyrażają w zależności od okoliczności: ironię, zdziwienie, nienawiść, zachwyt, radość, pogardę i zadowolenie; 2) milusi, cacany oraz klaaasa, no-no-no! - te z kolei wołacze i wykrzykniki oznaczają ironię, zdziwienie, zachwyt, nienawiść, radość, pogardę i zadowolenie (Ilf i Pietrow, 1991, s. 195-196). Ubogi był także język Ferdynanda Wspaniałego - gadającego psa wykreowanego przez L.J. Kerna, a przypomnianego przez Marię Nagajową w książce Stowo do słowa. Ferdynand Wspaniały nie znał m.in. żadnych określeń kolorów i kształtów, w jego idiolekcie nieobecne były też nazwy części garderoby, nazwy potraw czy zwroty grzecznościowe. „Na usprawiedliwienie Ferdynanda można jednak powiedzieć, że miał trudności tylko w pierwszych chwilach posługiwania się językiem. W miarę upływu czasu mówił coraz częściej i coraz lepiej” (Nagajowa, 1982, s. 5).

2 Sprawozdania te są dostępne na stronie Rady Języka Polskiego w zakładce Sprawozdania o stanie ochrony języka polskiego (http://www.rjp.pan.pl/index. 
SRJP dla sprawozdania Rady Języka Polskiego oraz RJP - dla nazwy instytucji) oraz 2) w poradniku ${ }^{3}$ Komunikacja pisemna. Rekomendacje (dalej stosuję skrót KPR) wydanym przez Kancelarię Prezesa Rady Ministrów (KPR, 2017).

Zaniedbania językowe mogą dotyczyć wszystkich i/lub kilku sfer języka (np. niechlujnej wymowy, nietrafionej fleksji, nieprecyzyjnego słowotwórstwa, niedoborowego słownictwa, zagmatwanej składni czy nieeleganckiego stylu). Zdaniem Jerzego Bralczyka - język pomieści wszystko, ponieważ to, co do języka wejdzie, już w nim pozostaje. W języku lokuje się zatem: 1) każde zapożyczone słowo (zob. anglicyzmy leksykalne ${ }^{4}$ występujące w zawodowych odmianach języka oraz w polszczyźnie ogólnej, np. kompatybilny), 2) każdy neosemantyzm, czyli angielski sens wyrazu przejmowany przez język polski (zob. leksem promocja ${ }^{5}$, który aktualnie znaczy „lansowanie towaru, często połączone z obniżką ceny"), czy 3) każda struktura składniowa (m.in. szerzący się pod wpływem języka angielskiego szyk wyrazów, np. sport telegram zamiast telegram sportowy).

php?option=com_content\&view=article\&id=1835:sprawozdania-o-stanie-ochrony-jezyka-polskiego\&catid=100\&Itemid $=53 ; 19.05 .2020$ ).

3 Źródłem informacji i porad normatywnych dla pracowników administracji państwowej jest także Vademecum tłumacza. Wskazówki redakcyjne dla tłumaczy (dalej stosuję skrót VT).

4 Zob. opinię Andrzeja Markowskiego na temat zapożyczeń: „Liczbę najnowszych zapożyczeń anglosaskich w języku można szacować na kilkaset. Wydawać by się mogło, że to niewiele, należy jednak zwrócić uwagę na fakt, że są to wyrazy często używane w prasie, radiu i telewizji, spotykane na szyldach i ogłoszeniach i w związku z tym upowszechniające się szybko w polszczyźnie (np. aborcja, asertywny, body, chips, cornflakes, fitness club, hamburger, hard rock, internauta, legginsy, monitoring, poster, puzzle, ranking, shop, sponsor, terminal, topless, windsurfing itp.)" (Markowski, 2008, s. 144).

5 Niebezpiecznym zjawiskiem dla status quo języka polskiego jest ingerencja w składnię dokonywana pod wpływem neosemantyzacji. „Niektóre wyrazy, nabrawszy nowego znaczenia, zmieniły też składnię. Nominacja jako synonim »wytypowania do jakiejś nagrody, do jakiegoś tytułu « ma składnię nominacja do czegoś (nominacja do Wiktorów, do tytułu »Kobieta Roku«; tradycyjnie: nominacja na coś) [...]" (Markowski, 2008, s. 145). Zob. także kolejną zmianę w znaczeniu (i łączliwości) tego słowa pod wpływem akcji z czasów pandemii (wiosna 2020 roku) nominacja do udziatu $w$ akcji \#Hot16Challenge2. 


\section{Na kanwie przemian - podbudowa metodologiczna artykułu}

Jak zauważa Kazimierz Ożóg ${ }^{6}$ w artykule zatytułowanym Polszczyzna pierwszej dekady XXI w. - próba uchwycenia najważniejszych zjawisk, rok 1989 wyznacza istotną granicę nie tylko w historii Polski, lecz także w dziejach języka polskiego ${ }^{7}$. „Od tego roku obserwujemy w naszym kraju gwałtowne przemiany w polszczyźnie, zmiany odzwierciedlające wielość przeobrażeń politycznych, obyczajowych, ekonomicznych i szerzej - kulturowych, zachodzących z taką intensywnością w ciągu ostatnich 20 lat” (Ożóg, 2009, s. 21). Zmiany historyczne na różnych płaszczyznach - jak dalej zaznacza autor - „przyniosły także nową jakość języka polskiego” (Ożóg, 2009, s. 21). Jaka jest ta jakość? Jakie znaczenie Polacy przywiązują do języka etnicznego? Jak język traktują? Na te i inne pytania nie ma jednoznacznej odpowiedzi. Wiele kwestii wymaga stałej analizy, gdyż język ciągle się zmienia. Ślady tych zmian widać nie tylko w postaci nowych wyrazów, lecz także w konstrukcjach składniowych, w budowie tekstu czy w odmianach języka. Kazimierz Ożóg wyróżnia trzy domeny zmian, które pod wpływem rzeczywistości zachodzą w języku od lat 80. XX wieku. Są to:

1. Domena zmian w obrębie języka oficjalnego i potocznego (aktywna do połowy lat 90. XX wieku). „Radykalnie zmieniła się z tego powodu zarówno polszczyzna oficjalna, jak i potoczna, bo także słowa [...]

6 Kazimierz Ożóg - badacz współczesnej polszczyzny, autor m.in. poczytnej książki Polszczyzna przełomu XX $i$ XXI wieku, która po raz pierwszy ukazała się w 2001 roku. Od tego czasu doczekała się wznowień zawierających poprawki i uzupełnienia (2004, 2007, 2011).

7 „Rok 1989 jest dla zmian językowych datą umowną, gdyż zmiany te zaczęły się już w roku 1980 z chwilą powstania Solidarności. Jednak 1989 rok zainicjował przez historyczne wydarzenia, m.in. przez obrady Okrągłego Stołu, częściowo demokratyczne wybory z 4 czerwca i powstanie rządu Tadeusza Mazowieckiego, proces zmian gwałtownych, które ciągle następują” (Ożóg, 2011, s. 21). „Gazeta Wyborcza”, czyli „pierwsza niezależna gazeta w bloku sowieckim” (Wójcik, 2019, s. 3), opublikowała w maju 2019 roku specjalne wydanie zatytułowane Wyborcza 1989. Ludzie. Życie. Styl poświęcone przełomowemu znaczeniu roku 1989. W tej wspomnieniowej antologii znajduje się wywiad Michała Nogasia z Teresą Kruszoną (Nie czeszę tekstów na gładko), który dotyczy stylu dziennikarskiego skrojonego na miarę mediów po 1989 roku. „»Wyborcza «” - choć na początku popełnialiśmy błędy - zawsze przywiązywała wagę do języka. Zaczęliśmy wyznaczać standardy języka prasy" (Nogaś, 2019, s. 127). 
uzyskały wolność i Polacy zaczęli w nowych warunkach inaczej mówić o sprawach publicznych i prywatnych" (Ożóg, 2011, s. 22).

2. Domena wpływów zachodnich tendencji kulturowych (aktywna od drugiej połowy lat 90. XX wieku). „Zaliczyć do nich należy: tendencje postmodernistyczne, konsumpcjonizm, medialność, rewolucję informatyczną oraz modną amerykanizację. Zespół tych czynników ciągle działa na polszczyznę, zmieniając ją na różnych poziomach, zwłaszcza na poziomie parole, w sposobach budowy tekstów" (Ożóg, 2011, s. 22).

3. Domena integracji Polski z Unią Europejską (od 1.05.2004 roku). „Unia Europejska oddziaływała na nasz język i przed wstąpieniem Polski w jej struktury, jednak ten wpływ nie był tak wielki jak obecnie" (Ożóg, 2011, s. 22).

Pod koniec pierwszej dekady XXI wieku intensyfikacji podlegały zjawiska, które wynikały z oddziaływania domeny drugiej i trzeciej. W niniejszym artykule pragnę zwrócić uwagę na pewne zmiany, jakie dokonały się w różnogatunkowych tekstach tworzonych przez instytucje państwowe (domena pierwsza i/lub domena trzecia). W tym celu odwołuję się do opracowań językoznawczych oraz do dokumentów rządowych lub na polecenie rządu (u)tworzonych. W drugiej dekadzie XXI wieku Rada Języka Polskiego, która jest instytucją opiniodawczo-doradczą w sprawach używania języka polskiego $^{8}$, opublikowała cztery sprawozdania, które dotyczą: języka polskiego w dokumentach używanych w obrocie konsumenckim (SRJP 2012-2013), promocji polszczyzny na stronach ambasad, konsulatów i Instytutów Polskich (SRJP 2015-2016), języka informacji politycznej (SRJP 2016-2017). W niniejszej analizie koncentruję się na sprawozdaniu z lat 2010-2011 noszącym tytuł Sprawozdanie ze stanu ochrony języka polskiego w latach 2010-2011 (SRJP 2010-2011) (http://www.rjp.pan.pl/images/Sprawozdania_o_stanie_ochrony_j\%C4\%99zyka/2010-2011.pdf; dostęp: 14.05.2020). Przedmiotem analizy czynię wybrane fragmenty tego sprawozdania. Dostrzeżone w tym dokumencie zaniedbania językowe odnoszę do uwag sformułowanych w poradniku Komunikacja pisemna. Rekomendacje (KPR), wydanym przez Kancelarię Prezesa Rady Ministrów (Warszawa, 2017).

8 Rada Języka Polskiego działa jako komitet problemowy w rozumieniu art. 34 ustawy z dnia 25 kwietnia 1997 roku o Polskiej Akademii Nauk (Dz. U. poz. 469, z późn. zm.). Rada (nie rzadziej niż co dwa lata) przedstawia Sejmowi i Senatowi sprawozdanie o stanie ochrony języka polskiego w rozumieniu art. 3 (https://sip.lex.pl/ akty-prawne/dzu-dziennik-ustaw/jezyk-polski-16854899/roz-3; 24.05.2020). 


\section{Sprawozdanie Rady Języka Polskiego 2010-2011}

Współautorzy SRJP 2010-20119 zajmowali się analizą wybranych oficjalnych dokumentów ośmiu instytucji państwowych. Przedmiotem szczegółowych badań uczynili strony internetowe siedmiu ministerstw i jednej instytucji centralnej. Były to strony: Ministerstwa Edukacji Narodowej, Ministerstwa Szkolnictwa Wyższego i Nauki, Ministerstwa Pracy i Polityki Społecznej, Ministerstwa Kultury i Dziedzictwa Narodowego, Ministerstwa Sportu i Turystyki, Ministerstwa Środowiska, Ministerstwa Zdrowia i Narodowego Funduszu Zdrowia. „Wybór tych właśnie ministerstw został podyktowany nie tylko względami merytorycznymi, tj. interesującą zawartością stron internetowych, lecz także względami emocjonalnymi, cóż bowiem jest ważniejsze dla człowieka niż zdrowie, kultura, nauka, edukacja, sport, środowisko i praca. Celem niniejszego raportu sporządzonego zgodnie ze statutowymi zadaniami Rady Języka Polskiego jest odpowiedź na pytanie, czy w komunikowaniu się ministerstw z obywatelami widać troskę i rzetelną dbałość o kulturę języka i kulturę komunikacji” (Kołodziejek, SRJP 2010-2011, s. $5^{10}$ ).

Pisemne redagowanie tekstów to biegłość, która wymaga koordynacji różnych kompetencji (składniowej, interpunkcyjnej, ortograficznej, leksykalnej, stylistycznej czy morfologicznej), dlatego w artykule pragnę zwrócić uwagę czytelnika na niepokojące zjawiska (zaniedbania językowe): kryzys leksyki i kryzys zdania w oficjalnej odmianie polszczyzny. O kryzysie leksyki (zob. zjawiska leksykalne deprecjonujące język: od nieprzemyślanej neologizacji i neosemantyzacji do brutalizacji i wulgaryzacji leksyki) piszą językoznawcy z wielu ośrodków badawczych, zjawisko to dostrzegają także użytkownicy języka, którzy nie są językoznawcami. Z kolei mniej zauważalny, ale bardzo niebezpieczny dla autonomii języka, jest kryzys drugi, który Kazimierz Ożóg

9 Grono współautorów tworzą: Andrzej Markowski, Walery Pisarek, Ewa Kołodziejek oraz sprawozdawcy piszący o dokumentach oficjalnych dostępnych w internetowych zasobach wybranych ministerstw i instytucji rządowych: Agnieszka Szczaus, Jolanta Ignatowicz-Skowrońska, Krzysztof Skibski, Małgorzata Witaszek-Samborska, Rafał Zimny, Rafał Sidorowicz, Agnieszka Kula.

10 W artykule podaję numery stron zgodnie z numeracją ciągłą SRJP 2010-2011 $\mathrm{w}$ formacie PDF. Nadmieniam jednak, że cały dokument (w numeracji ciągłej liczący 238 stron) jest antologią kilku różnych dokumentów, sygnowanych przez kilku sprawozdawców, a każdy z tych dokumentów ma odrębną numerację. 
nazwał kryzysem zdania, odnosząc go do odmiany mówionej (potocznej, nieoficjalnej) i pisanej (ogólnopolskiej, oficjalnej).

O kryzysie zdania w odmianie nieoficjalnej Ożóg pisze następująco: „Kryzys zdania przejawia się w dominacji wyrażeń emocjonalnych, w prymitywnej, ubogiej co do liczby składników budowie, w unikaniu łączenia różnych treści w zdania złożone, w omijaniu spójników, które wyrażają związki logiczne" (Ożóg, 2011, ss. 27-28).

Kryzys zdania dotyka także komunikację oficjalną (np. teksty naukowe lub publikacje do takiego miana pretendujące). „Z moich badań wynika, że studenci niechętnie tworzą oryginalne teksty, wolą komponować je na podstawie tekstów internetowych. Jeśli już piszą samodzielnie, to najczęściej stosują zdania pojedyncze, co najwyżej podwójnie złożone przydawkowe. Dzisiaj zdanie wielokrotnie złożone w tekstach uczniów czy studentów jest prawdziwą rzadkością. Akapity i całości informacyjne są już w zupełnym odwrocie. Nie umiemy mówić pełnymi zdaniami, zanika też umiejętność narracji, czyli pięknego opowiadania. W tekstach mówionych częstym zjawiskiem jest dodawanie modułów informacji bez precyzyjnego formalnego przyporządkowania logicznego" (Ożóg, 2011, s. 28).

Dlatego w kolejnych podrozdziałach (3.1. oraz 3.2.) koncentruję się na leksykalno-ortograficznych i składniowo-interpunkcyjnych odstępstwach od normy językowej w dokumentach upublicznianych w sieci przez Ministerstwo Edukacji Narodowej ${ }^{11}$ (SRJP 2010-2011, Szczaus, ss. 32-53) oraz Ministerstwo Nauki i Szkolnictwa Wyższego ${ }^{12}$ (SRJP 2010-2011, Ignatowicz-Skowrońska, ss. 55-111).

Zwracając uwagę na fakt, że zaniedbania językowe można odnaleźć w dokumentach państwowych, równocześnie odnotowuję istnienie poradników (o jednym $\mathrm{z}$ nich piszę $\mathrm{w}$ rozdziale 4.), dzięki którym urzędnicy mogą doskonalić polszczyznę oficjalną. Chociaż bliskie jest mi stanowisko Jerzego Bartmińskiego, „który podziwia ten żywioł, jakim jest język, patrzy, jak on się krzewi i rozkwita" (Bartmiński, 2012, s. 63), to pragnę poprzez swoją analizę przypomnieć i podkreślić, że język jest naszym wspólnym dobrem, a odpowiedzialność za jego jakość w najwyższym stopniu ponoszą autorzy analizowanych dokumentów (politycy, urzędnicy).

11 Analiza liczy 22 strony, a w numeracji ciągłej dokumentu SRJP 2010-2011 obejmuje strony 32-53.

12 Analiza liczy 57 stron, a w numeracji ciągłej SRJP 2010-2011 obejmuje strony $55-111$. 


\section{SRJP 2010-2011 dotyczące języka dokumentów MEN}

Analiza sporządzona przez Agnieszkę Szczaus ${ }^{13}$ dotyczyła 200 losowo wybranych tekstów (różniących się tematycznie i gatunkowo), które pozwoliły wychwycić najczęstsze zaniedbania językowe.

W oficjalnych dokumentach niepokoi obecność błędów ortograficznych, wynikająca z nieznajomości reguły dotyczącej pisowni partykuły nie z rzeczownikami odczasownikowymi (np. nieparkowanie), zob. przykład (1).

(1) Za kontynuacja programu po 2013 r. oraz *nie taczeniem go z innymi inicjatywami UE przemawia również fakt, iż jest to program najbardziej ekonomicznie dostosowany do możliwości i zapotrzebowania środowiska mtodzieżowego (SRJP 2010-2011, Szczaus, ss. 33-34).

Zaprzeczone rzeczowniki odczasownikowe są często używane w komunikacji oficjalnej, a ponieważ nazywają czynności (np. łączenie), dlatego mogą być postrzegane jak czasowniki, co prawdopodobnie prowadzi do stosowania wobec ich form zaprzeczonych (zob. niełaczenie) reguły o rozłącznej pisowni partykuły nie z czasownikami.

Jak wynika $\mathrm{z}$ analizy, wyrazem trudnym do napisania jest przymiotnik złożony z liczebnika i słów typu rok, miesiąc. Złożenia takie można zanotować dwojako: albo słownie, albo łącząc zapis cyfrowy z zapisem słownym za pomocą łącznika (bez spacji), zob. przykłady (2)-(3).

(2) 3,5-letni oraz trzyipótletni.

(3) 12-miesięczy oraz dwunastomiesięczny.

Przyczyna tego błędu leży prawdopodobnie w nieznajomości reguły dotyczącej pisowni wyrazów złożonych, które zawierają liczbę lub literę w pierwszej części (zob. https://sjp.pwn.pl/zasady/W-wyrazach-zlozonych-z-liczba-lub-litera-w-pierwszej-czesci;629548.html; 2.05.2019).

Do zjawisk niebezpiecznych dla status quo języka polskiego można zaliczyć neosemantyzację oraz natrętne zapożyczenia. Neosemantyzacji uległo m.in. słowo delegować. Rozszerzenie jego znaczenia „nastąpiło pod wpływem angielskiego to delegate 'przekazać, zlecić coś komuś', a zwrot delegować zadania i wyrażenie delegowanie zadań upowszechniły się w podręcznikach do zarządzania, często tłumaczonych z języka angielskiego. Teraz obie konstruk-

13 Pełny tytuł analizy brzmi: Poprawność językowa i sprawność komunikatywna materiatów pisemnych kierowanych do obywateli przez Ministerstwo Edukacji Narodowej (na przykładzie tekstów z lat 2010-2011 zamieszczonych na stronach internetowych ministerstwa) (SRJP 2010-2011, Szczaus, ss. 32-52). 
cje przenikają do innych odmian polszczyzny" (SRJP 2010-2011, Szczaus, s. 43). Do kategorii niepotrzebnych zapożyczeń badaczka zaliczyła słowa implementacja (zob. przykład 4) oraz ewaluacja. Pierwsze z nich proponuje zastąpić słowem realizacja, zob. przykład (4.1.).

(4) Rola organizacji młodzieżowych $w$ "implementacji polityki młodzieżowej (SRJP 2010-2011, Szczaus, s. 44).

(4.1.) Rola organizacji młodzieżowych $w$ realizacji polityki młodzieżowej.

Trudniej jest polemizować z nadużywaniem słowa ewaluacja, bo rzeczownik ten pojawił się „w Rozporządzeniu Ministra Edukacji Narodowej i Sportu z 23 kwietnia 2004 roku i został zdefiniowany jako »obiektywna ocena projektu, programu lub polityki na wszystkich jego etapach, tj. planowania, realizacji i mierzenia rezultatów. Powinna ona dostarczyć rzetelnych i przydatnych informacji, pozwalając wykorzystać zdobytą w ten sposób wiedzę w procesie decyzyjnym. Często dotyczy ona procesu określenia wartości lub ważności działania, polityki lub programu«. Trudno zatem całkowicie zrezygnować z używania terminu, który funkcjonuje w oficjalnym dokumencie" (SRJP 2010-2011, Szczaus, ss. 44-45). Zakres użycia słowa ewaluacja (zob. przykład 5) jest zbyt szeroki, dlatego autorka sugeruje synonim ocena, jak w przykładzie (5.1.).

(5) Wszystkie lekcje byty zakończone "ewaluacją. (SRJP 2010-2011, Szczaus, s. 44).

(5.1.) Wszystkie lekcje byty zakończone ocena.

Ryzyko błędu składniowego czy interpunkcyjnego wzrasta wraz z długością zdania: na ogół im dłuższe zdanie i im bardziej skomplikowana jego struktura, tym ryzyko większe. Autorka sprawozdania zwróciła uwagę na pomijanie przecinka oraz niewydzielanie przecinkami (otwierającym i zamykającym) zdań składowych w zdaniach złożonych różnego typu, zob. przykłady (6)-(7).

(6) *Ofertę takich zajęć przygotowuje dyrektor szkoty w porozumieniu $z$ rodzicami i nauczycielami biorac pod uwage potrzeby $i$ zainteresowania uczniów. (SRJP 2010-2011, Szczaus, s. 38).

(7) * $Z$ artykutu nie sposób wywnioskować na jakiej podstawie oparte jest twierdzenie, że MEN zmienia plany w kwestii wydawania podręczników $w$ wersji elektronicznej. (SRJP 2010-2011, Szczaus, s. 38).

W zdaniu (6) przecinek powinien wydzielić imiesłowowy równoważnik zdania (biorac pod uwagę potrzeby i zainteresowania uczniów). W zdaniu (7) pominięty został przecinek otwierający zdanie podrzędne (na jakiej podstawie oparte jest twierdzenie).

Obserwacje dotyczące składni i interpunkcji mają charakter uniwersalny odnoszą się do wszystkich poddanych analizie dokumentów rządowych, tym 
samym potwierdzając kryzys zdania w języku polskim. Poczynione do tej pory analizy pozwalają na następującą sugestię (znaną nie od dziś): pisemna odmiana języka polskiego wymaga stosowania takich zdań, których składniki są od siebie oddalone o 5 do 9 wyrazów. „Victor Ingve dowodził przed kilku laty, że liczbę określeń poprzedzających wyraz określany ogranicza właściwość umysłu ludzkiego. Nie może on uchwycić sensu wyrażenia, jeśli podstawę poprzedza więcej niż $7( \pm 2)$ określeń. Bliską granicy zrozumiałości jest więc na przykład według Victora Ingve fraza: very much more clearly projected pictures of Rome. Mianownikową podstawę tej frazy (pictures) poprzedza pięć określeń, a więc niedaleko stąd już do wspomnianej magicznej liczby 7士2" (Pisarek, 2007, ss. 226-227, zob. także Pisarek, 2002 ${ }^{14}$ ).

W dalszej części artykułu (podrozdział 3.2.) przechodzę do analizy wybranych kwestii leksykalno-ortograficznych dostrzeżonych w dokumentach $\mathrm{MNiSW}^{15}$.

\section{SRJP 2010-2011 dotyczące języka dokumentów MNiSW}

Kolejny rozdział SRJP 2010-2011 nosi tytuł Strony internetowe Ministerstwa Nauki i Szkolnictwa Wyższego - budowa, użyteczność, analiza zawartości (style, gatunki, poprawność językowa) ${ }^{16}$ (SRJP 2010-2011, Ignatowicz-Skowrońska, ss. 55-111).

14 Publikacja z roku 2002 (Nowa retoryka dziennikarska) dotyczy doskonalenia warsztatu pisarskiego (Pisarek, 2002). W drugiej (O mediach $i$ języku) warte przestudiowania (z punktu widzenia rozwijania tego warsztatu) są m.in. rozdziały Recepta na zrozumiatość wypowiedzi oraz Jak mierzyć zrozumiałość tekstu? (Pisarek, 2007, ss. 223$-262)$.

15 W kolejnym podrozdziale pomijam analizę dotyczącą składni, ponieważ obserwacje poczynione przez autorki obu raportów oraz przez badaczy pozostałych dokumentów ministerialnych są podobne.

16 „Raport obejmuje analizę zawartości serwisu internetowego Ministerstwa Nauki i Szkolnictwa Wyższego. Jej celem było sprawdzenie estetyki, budowy i funkcjonalności stron WWW, zróżnicowania gatunkowo-stylistycznego prezentowanych tam materiałów pisemnych oraz ich poprawności językowej. Badania prowadzono w lipcu i sierpniu 2012 roku. Objęto nimi materiały pisemne datowane na lata 2009-2011. Szczegółowej analizie poddano próbę 200 tekstów pobranych z następujących stron: aktualności; nauka; szkolnictwo wyższe; inicjatywy; zarządzanie kryzysowe, ochrona informacji niejawnych, sprawy obronne; patronaty; festiwale nauki; zdaniem ministra; dla mediów; komunikaty; konferencje i szkolenia; reforma nauki; zespoły ministra, finansowanie szkolnictwa wyższego" (SRJP 2010-2011, Ignatowicz-Skowrońska, s. 57). 
Autorka raportu zwraca uwagę na nadużywanie wielkich liter w pisowni nazw stanowisk, godności, tytułów naukowych czy zawodowych oraz w pisowni tytułów (np. aktów prawnych) cytowanych w informacjach kierowanych przez MNiSW do odbiorców. W tym względzie pisownię polską regulują: 1) zasada [85] 18.28. dotycząca pisowni nazw urzędów jednoosobowych w aktach prawnych ${ }^{17}$ oraz 2) zasada [73] 18.16. dotycząca pisowni pierwszego wyrazu w jedno - i wielowyrazowych tytułach ${ }^{18}$.

Niektóre oficjalne zapisy ministerialne - jak zauważa Ignatowicz-Skowrońska - nie spełniają zasady [85] 18.28., zob. przykład (8).

(8) [...] ankiety aplikacyjne zostały złożone w terminie do 31 lipca 2009 r. i uzyskaty pozytywnq ocenę zespołów specjalistycznych powołanych przez *Ministra do oceny czasopism naukowych. (SRJP 2010-2011, Ignatowicz-Skowrońska, s. 79).

Zasada [73] 18.16. nie ma zastosowania, gdy nazwa nie jest pełna, jak w przykładzie (9). Najbardziej jednak razi niekonsekwencja w zapisie nazwy jakiegoś dokumentu (niepełna nazwa, a zapis wielką literą), zob. przykład (10).

17 Przytaczam fragment zasady [85] 18.28.: „Chociaż małą literą piszemy nazwy godności współczesnych i historycznych oraz tytułów naukowych i zawodowych (np. prezydent Rzeczypospolitej Polskiej, premier, wojewoda ślaski, profesor Uniwersytetu Łódzkiego), to nazwy urzędów jednoosobowych w aktach prawnych pisze się wielką literą: [...] akceptuje Prezydent Rzeczypospolitej Polskiej; [...] zatwierdza Prezes Rady Ministrów; Obrady Sejmu otwiera Marszałek Sejmu Rzeczypospolitej Polskiej; Rzecznik Praw Obywatelskich ma uprawnienia w zakresie [...]. Jednak zgodnie ze zwyczajem pisownię wielkimi literami można stosować również w tekstach o innym przeznaczeniu, pod warunkiem że nazwa taka odnosi się do konkretnej osoby i występuje w pełnym brzmieniu: Dziś Prezydent Rzeczypospolitej Polskiej odwiedzit nasze miasto; Jan Kowalski zostat powołany na stanowisko Wojewody Koszalińskiego; Zebranie otworzyt Naczelnik Gminy Brzezinka Łukasz Rudzki" (https://sjp.pwn.pl/zasady/Nazwy-urzedowjednoosobowych-w-aktach-prawnych;629404.html; 28.05.2020).

18 Kluczowy fragment zasady [73] 18.16. brzmi: „Wielką literą piszemy pierwszy wyraz w jedno- i wielowyrazowych tytułach utworów literackich i naukowych (np. książek, rozpraw, artykułów, wierszy, pieśni, piosenek, filmów, sztuk teatralnych), w tytułach ich rozdziałów, w tytułach dzieł sztuki, zabytków językowych, odezw, deklaracji, ustaw, akcji charytatywnych i porządkowych, operacji wojskowych". Po tym wyliczeniu wymienionych zostało ponad 50 przykładowych tytułów jedno- i wielowyrazowych. W świetle analizowanych przykładów warta przytoczenia jest także uwaga zamykająca: „Tytuły ustaw przytaczane w pełnym brzmieniu pisze się wielką literą, np. Ustawa o wychowaniu w trzeźwości i przeciwdziałaniu alkoholizmowi, Ustawa o postępowaniu w sprawach nieletnich. Nazwy skrócone, przywoływane w znaczeniu potocznym, zapisujemy mała literą, np. ustawa antyalkoholowa, ustawa o nieletnich" (https://sjp.pwn.pl/zasady/7318-16-Pierwszy-wyraz-w-jedno-i-wielowyrazowych-tytulach;629391.html; 28.05.2020). 
(9) Szczegółowe informacje dotyczace przeprowadzenia konkursu i realizacji zatwierdzonych do finansowania projektów można znaleźć $w$ *Rozporzadzeniu Ministra Nauki i Szkolnictwa Wyższego z dnia 22 stycznia 2008 r. [...]. (SRJP 2010-2011, Ignatowicz-Skowrońska, s. 80).

(10) Narodowy Program Rozwoju Humanistyki zostat ustanowiony Komunikatem Ministra Nauki i Szkolnictwa Wyższego z dnia 5 listopada 2010 r. (SRJP 2010-2011, Ignatowicz-Skowrońska, s. 80).

Pełna nazwa dokumentu, o którym mowa w przykładzie (9), brzmi: Rozporzadzenie Ministra Nauki i Szkolnictwa Wyższego z dnia 22 stycznia 2008 r. w sprawie kryteriów i trybu przyznawania oraz rozliczania środków finansowych na nauke przeznaczonych na finansowanie projektów badawczych. Z kolei tytuł komunikatu, na który powołano się w przykładzie (10), to: Komunikat Ministra Nauki i Szkolnictwa Wyższego z dnia 5 listopada 2010 r. o ustanowieniu programu pod nazwa „Narodowy Program Rozwoju Humanistyki” (http://prawo.sejm.gov.pl/isap.nsf/DocDetails.xsp?id=WMP20100861014; 28.05.2020).

Zdaniem Jolanty Ignatowicz-Skowrońskiej bardziej niepokoić powinna rozpowszechniona we współczesnej polszczyźnie oraz na stronach serwisu internetowego MNiSW „praktyka pisania wielkimi literami wszystkich samodzielnych znaczeniowo leksemów będących składnikami wielowyrazowych tytułów utworów literackich czy naukowych" (Ignatowicz-Skowrońska, SPRJ 2010-2011, s. 81), a także niezgodna z normą pisownia wielkimi literami nazw dziedzin nauki i dyscyplin naukowych. Obie obserwacje ilustrują przykłady (11)-(12).

(11) Od 1994 r. FNP dofinansowuje wydawanie dziet seryjnych zawierajacych naukowa dokumentację dziedzictwa historycznego i cywilizacyjnego Polski (np. "Stownik Polszczyzny XVI w. czy *Polski Stownik Biograficzny). (SRJP 2010-2011, Ignatowicz-Skowrońska, s. 81).

(12) Dyscyplina naukowa: *Nauki Społeczne i Polityczne. (SRJP 2010-2011, Ignatowicz-Skowrońska, s. 81).

Tytuły z przykładu (11) powinny mieć postać: Słownik polszczyzny XVI wieku i Polski słownik biograficzny. Natomiast nazwy dziedzin nauki i dyscyplin naukowych należy pisać małymi literami ${ }^{19}$, zob. prawidłowy zapis w przykładzie (12.1.).

19 Jak czytamy w poradniku językowym Piszemy poprawnie: „reguły pisowni nie rozstrzygają tego problemu wprost, ale też żadna z zasad zapisu wielkimi literami nie może mieć tu zastosowania. Stąd wniosek, że nazwy kierunków studiów, specjalizacji akademickich należy zapisywać małymi literami, tak samo jak nazwy przedmiotów szkolnych. [...] Zapisy wielkimi literami mogą wystąpić tylko w nazwach własnych, np. Wydział Zarzadzania i Marketingu" (Kubiak-Sokół, 2008, s. 71). 
(12.1.) Dyscyplina naukowa: nauki spoteczne i polityczne.

W sferze leksykalnej w analizowanych przez Jolantę Ignatowicz-Skowrońską dokumentach MNiSW na uwagę zasługuje popularność pewnych leksemów (neosemantyzmów), np. wyraz obszar pod wpływem języka angielskiego jest używany w znaczeniu „dziedzina czegoś, zakres”. Zakres znaczeniowy poszerzyło także słowo wydarzenie, którym określane są m.in. „konferencje naukowe", co jest o tyle niebezpieczne, że oznacza rezygnację z synonimów spotkanie, sesja, zjazd itp. Typowym przykładem anglosemantyzmu jest gerundium aplikowanie w znaczeniu „staranie się o przyjęcie (np. na studia, do pracy); ubieganie się o stypendium" (SRJP 2010-2011, Ignatowicz-Skowrońska, ss. 93-94), a także rzeczownik aplikacja i przymiotnik aplikacyjny, które również nabrały nowych znaczeń. Aplikacja w znaczeniu informatycznym to „program komputerowy przeznaczony do określonych zadań, np. edytor tekstów”, a w nowym znaczeniu - to "podanie w sprawie zatrudnienia, ubieganie się o jakieś stanowisko" (SRJP 2010-2011, Ignatowicz-Skowrońska, s. 94).

Anglosemantyzmów w oficjalnych dokumentach jest więcej. Wybrane z nich wymieniam, podając krótko ich nowe znaczenia: dedykowany „poświęcony”, przyjazna instytucja „instytucja, w której petent jest profesjonalnie obsługiwany", inteligentna maszyna "urządzenie, które rozpoznaje oczekiwania użytkownika”, filozofia „sposób robienia czegoś, metoda, koncepcja, idea" (SRJP 2010-2011, Ignatowicz-Skowrońska, s. 95). Zaniedbaniom (nadużyciom) leksykalnym i frazeologicznym poświęca Ignatowicz-Skowrońska dziesięć stron sprawozdania (SRJP 2010-2011, Ignatowicz-Skowrońska, ss. 91-99). W podsumowaniu podrozdziału o błędach leksykalnych stwierdza: „Uchybienia leksykalne dotyczyły odpowiednio: nadużywania wyrazów modnych typu priorytet, wizja, platforma, potencjat, kreowanie, korespondować, kondycja, wprowadzania mody językowej na nowe, dotychczas nienadużywane wyrazy (por. wydarzenie, obszar) i upowszechniania anglosemantyzmów (na przykład: aplikacja, aplikowanie, aplikacyjny, dedykowany, przyjazny, inteligentny, prezydencja)" (SRJP 2010-2011, Ignatowicz-Skowrońska, s. 99).

Zrozumiałym zjawiskiem jest dążenie do internacjonalizacji leksyki, ale warte rozważenia są także głosy obrońców rodzimej leksyki: „Teza, że wyrazy obce utrudniają zrozumienie tekstu, wydaje się oczywista. Potwierdzają ją wypowiedzi stylistyków i psychologów, listy czytelników narzekających, że niektórych artykułów w prasie nie można zrozumieć bez słownika, oraz codzienne doświadczenie (kiedy pytamy o znaczenie jakiegoś słowa, zazwyczaj chodzi o wyraz obcy)" (Pisarek, 2002, s. 187). 


\section{Komunikacja pisemna. Rekomendacje (2017)}

Konieczność doskonalenia języka dostrzegają (współ)autorzy poradnika Komunikacja pisemna. Rekomendacje ${ }^{20}$ wydanego przez Kancelarię Prezesa Rady Ministrów (Warszawa 2017, wyd. drugie, rozszerzone ${ }^{21}$ ). We wstępie czytamy m.in.: „Nawet o najtrudniejszych, najbardziej skomplikowanych sprawach możemy i chcemy pisać w sposób prosty, jasny i przystępny dla każdego" (KPR, Dowiat-Urbański, 2017, s. 3).

W KPR wypowiedział się także językoznawca Tomasz Piekot - kierownik i współtwórca Pracowni Prostej Polszczyzny ${ }^{22}$, dementując dwa mity związane $\mathrm{z}$ językiem urzędowym.

1) Mit o niskich kompetencjach językowych urzędników. „Polskim urzędnikom nie brakuje [...] językowej sprawności [...]. Brakuje im odwagi do zmiany tego, co zastane i utrwalone. Odwagi w projektowaniu nowych wzorów

20 Jak odnotowano w rozdziale Przyjazny język urzędowy (KPR, 2017, s. 9), istnieje kilka poradników dotyczących komunikacji oficjalnej, o których wydanie zadbały instytucje rządowe. „W 2010 r. Ministerstwo Rozwoju Regionalnego wydało podręcznik Jak pisać o Funduszach Europejskich?, który ma ułatwić tworzenie prostych i przystępnych dokumentów informacyjnych. Ten zbiór praktycznych wskazówek i porad, przygotowany przez ekspertów - polonistów pracujących pod kierunkiem profesora Jana Miodka - opracowany został na podstawie obszernych badań empirycznych. W roku 2012 Rzecznik Praw Obywatelskich, Wojewoda Mazowiecki i Rada Języka Polskiego zainicjowali projekt Język urzędowy przyjazny obywatelom, a dołączyli do nich wkrótce Senat RP oraz Szef Służby Cywilnej. [...] W 2013 r., pod redakcją naukową E. Czerwińskiej i R. Pawelca, ukazała się książka Polski z urzędu. O poprawności języka urzędowego, w której m.in. A. Markowski omawia podstawowe pojęcia kultury języka w odniesieniu do języka urzędowego oraz podstawowe cechy stylu urzędowego i ogólne zasady poprawnego formułowania tekstów urzędowych, a I. Burkacka - charakterystyczne dla stylu urzędowego słownictwo" (KPR, 2017, ss. 9-10).

21 Rozszerzenie obejmuje: 1) rozdział o komunikacji internetowej zawierający również wskazówki, jak pisać wiadomości przesyłane pocztą elektroniczną, a także 2) rozdział prezentujący najważniejsze zasady ortografii i interpunkcji. Adnotację o drugim rozszerzeniu opatrzono asekuracyjną uwagą: „Język polski jest piękny i jego bogactwo napawa nas dumą. Nasze doświadczenie pokazuje jednak, że wybór prawidłowej formy może sprawiać trudności nawet polonistom” (KPR, 2017, s. 4).

22 Tomasz Piekot to językoznawca i komunikolog, trener komunikacji interpersonalnej i społecznej. Istotę zrozumiałości języka oficjalnego sformułował m.in. w wykładzie zatytułowanym Jezzyk 3 pach, jaki wygłosił w Katowicach podczas konferencji TEDx w 2017 roku, zob. https://www.youtube.com/watch?v=3H81RpC75a0 (19.05.2020). 
pism, odwagi w parafrazowaniu regulacji, odwagi w nawiązywaniu z obywatelem relacji, których podstawą jest profesjonalizm partnera, a nie dystans czy surowość ojca. A przede wszystkim - polscy urzędnicy potrzebują odważnych zwierzchników, którzy im w tę nową wizję pomogą uwierzyć" (KPR, Piekot, 2017, s. 4).

2) Mit o niskich kompetencjach językowych Polaków - adresatów pism urzędowych. Tomasz Piekot zwrócił uwagę na nadmiar informacji, a tym samym - na konieczność ich selekcji oraz znajdowania informacji prawdziwych $^{23}$. „Potrzebujemy nowego języka z powodów cywilizacyjnych. Po prostu zalewa nas zbyt wiele informacji, których nie jesteśmy w stanie przetworzyć. Informacje te pisane są zazwyczaj stylem z czasów spokojnego życia na informacyjnej pustyni. Dziś obywatel (każdy, bez względu na wykształcenie) potrzebuje pism urzędowych w wersji light, potrzebuje językowej diety" (KPR, Piekot, 2017, s. 4).

Zgadzam się zarówno z opinią Piekota, jak i z opiniami innych językoznawców w kwestii zrozumiałości tekstów. Bliskie jest mi stanowisko Walerego Pisarka, który w Nowej retoryce dziennikarskiej zawarł taką obserwację: „A więc kiedy przyłapiesz się na tym, że piszesz jakieś zagmatwane zdanie, zapytaj sam siebie: - Jak bym to powiedział, gdyby czytelnik siedział na wprost mnie? Jak bym mu to powiedział przez telefon? Na pewno znajdziesz wtedy formę bez porównania prostszą" (Pisarek, 2007, s. 193).

Nie przytaczam porad rozpisanych w KPR dla kluczowych zagadnień dotyczących komunikacji pisemnej ${ }^{24}$. Wiele zaleceń koresponduje z opisem zaniedbań w SRJP 2010-2011. Warto jednak zaznaczyć, że niefortunne zjawiska językowe nie dotyczą tylko języka urzędowego, ale funkcjonują w różnych sferach komunikacji oficjalnej.

\section{Podsumowanie}

Zmiany historyczne na różnych płaszczyznach - jak zaznacza Kazimierz Ożóg - „przyniosły [...] nową jakość języka polskiego” (Ożóg, 2009, s. 21). Jaka jest ta jakość? Jakie znaczenie Polacy przywiązują do języka etnicznego?

23 Zob. wypowiedź Natalii Hatalskiej na temat infodemii zatytułowaną Mirrorworld, czyli pandemia vs infodemia (Hatalska, 2020).

24 Porady są dosyć oczywiste i lakoniczne. Po szczegółowe wyjaśnienia czytelnik KPR odsyłany jest (za pośrednictwem obszernej bibliografii) do różnych poradni i poradników z zakresu kultury języka. 
Jak język traktują? Na te i inne pytania nie ma jednoznacznej odpowiedzi. Wiele kwestii wymaga stałej analizy, gdyż język ciągle się zmienia. W palimpseście językoznawczych opinii widzę możliwość odnalezienia uniwersalnych wskazówek, jak język pielęgnować (w komunikacji oficjalnej i nieoficjalnej), jakie zabiegi profilaktyczne stosować, aby podnosić kompetencje i sprawności językowe Polaków. Inaczej mówiąc, jak nie dać się językowi skundlić, jak język szanować.

Kryzys językowy (leksykalny i składniowy) to zjawisko niepokojące, które może zagrażać tożsamości języka polskiego. Neologizmy, neosemnatyzmy, zapożyczenia, wyrazy modne zostają w tekstach i wypowiedziach, a ich żywotność jest zależna od mody i/lub potrzeby nazewniczej. Jeżeli okażą się fortunne, to prawdopodobnie zostaną, tzn. piszący czy mówiący po polsku dadzą im zielone światło (nastąpi przyswojenie, a także większa lub mniejsza asymilacja w języku). Elementy językowe niefortunne lub obecne w języku tylko przez jakiś czas (jak np. młodzieżowe słowo roku²5) do żywego języka (do jego aktywnych struktur) się nie przebiją lub zagoszczą tam tylko na chwilę. Ale zawsze pozostawią jakiś ślad.

Natomiast to, jak budujemy zdania w języku polskim i jak je zapisujemy (z przecinkami czy bez), odtwarza nasz sposób myślenia, naszą precyzję językową. Sztuką pisarską jest tak redagować teksty, nawet o sprawach zawiłych, aby odbiorca zrozumiał nadawcę, aby nie musiał się domyślać sensu nieskładnie zredagowanego komunikatu. I co do tego sposobu dbania o język nie można mieć wątpliwości, dlatego dbanie o precyzyjny i ekonomiczny język dokumentów oficjalnych to może być dobry prognostyk dla kondycji polskiego języka ogólnego i jego różnych odmian.

Poczyniona analiza potwierdza dynamiczne zmiany w obrębie języka oficjalnego (pierwsza domena zmian wyróżniona przez Kazimierza Ożoga), a także eksponuje wpływ języka angielskiego w warstwie leksykalnej i składniowej (trzecia domena zmian, jakie pod wpływem rzeczywistości zachodzą w języku). Najbardziej niebezpieczne dla status quo języka ojczystego

25 Jest to coroczny plebiscyt organizowany przez Wydawnictwo Naukowe PWN. Co znamienne - w tytule plebiscytu wskazywany jest rok jako rama czasowa dla żywotności zwycięskiego wyrazu i/lub wyrazów z nim konkurujących. Plebiscyt jest organizowany od roku 2016. Kolejno zwyciężały następujące słowa: sztos (2016), xD (2017), dzban (2018), alternatywka (2019). Poszczególne zwycięskie słowa w witrynie https://sjp.pwn.pl/mlodziezowe-slowo-roku/Komentarze-jezykoznawcy;202300.html (24.05.2020) komentowali m.in. Ewa Kołodziejek, Anna Wileczek, Bartek Chaciński, Marek Łoziński. 
są zmiany, które polegają na ingerencji w system gramatyczny rodzimego języka. Warto je (po)znać, aby się ich wystrzegać i aby przywiązując wagę do języka, wyznaczać standardy języka oficjalnego.

\section{Bibliografia}

Krzemińska, A. 2012. Z perspektywy botanika. Rozmowa z prof. Jerzym Bartmińskim o tym, czy język nas określa oraz czy globalizacja psuje język. Niezbędnik Inteligenta. Polityka. Wydanie Specjalne. O języku w mowie i piśmie. 11, ss. 62-65.

Ilf, I. i Pietrow, E. 1991. Dwanaście krzeset. Warszawa: Warszawska Oficyna Wydawnicza "Gryf”.

Krzemińska, A., Baczyński, J. i Będkowski, L. 2012. Co się dzieje z naszą mową? Niezbędnik Inteligenta. Polityka. Wydanie Specjalne. O języku w mowie i piśmie. 11, s. 3.

Kubiak-Sokól, A. (oprac.) 2008. Piszemy poprawnie. Poradnik językowy. Seria Akademia Języka Polskiego PWN. T. 9. Warszawa: Wydawnictwo Naukowe PWN.

Markowski, A. 2008. Kultura języka polskiego. Teoria. Zagadnienia leksykalne. Warszawa: Wydawnictwo Naukowe PWN.

Miodek, J. 2010. Stownik polsko@polski z Miodkiem. Rozmowy profesora Jana Miodka o języku polskim z telewidzami z kraju i ze świata. Wrocław: Wydawnictwo Marina.

Nagajowa, M. 1982. Stowo do stowa. Warszawa: WSiP.

Nogaś, M. 2019. Nie czeszę tekstów na gładko. Z Teresą Kruszoną rozmawia Michał Nogaś. Wyborcza 1989. Ludzie. Życie. Styl. 3, ss. 126-129.

Ożóg, K. 2001. Polszczyzna przełomu XX i XXI wieku. Wybrane zagadnienia. Rzeszów: Stowarzyszenie Literacko-Artystyczne „Fraza”.

Ożóg, K. 2009. Polszczyzna pierwszej dekady XXI w. - próba uchwycenia najważniejszych zjawisk. W: Dunaj, B. i Rak, M., red. Polszczyzna mówiona ogólna i regionalna. Materiały Ogólnopolskiej Konferencji Naukowej Kraków, 25-26 września 2008 r. Kraków: Księgarnia Akademicka, ss. 21-31.

Pisarek, W. 2002. Nowa retoryka dziennikarska. Kraków: TAiWPN „Universitas".

Pisarek, W. 2007. O mediach $i$ języku. Kraków: TAiWPN „Universitas”. Szostkiewicz, A., 2012. Mówta, co chceta? Niezbędnik Inteligenta. Polityka. Wydanie Specjalne. O jezzku w mowie i piśmie. 11, ss. 70-72. 
Wójcik, J. 2019. Mój chodnik, moje państwo. Wyborcza 1989. Ludzie. Życie. Styl. 3, s. 3.

\section{Analizowane dokumenty i skróty ich nazw}

(KPR) - Komunikacja pisemna. Rekomendacje. 2017. Departament Służby Cywilnej Kancelarii Prezesa Rady Ministrów, oprac. Warszawa: Kancelaria Prezesa Rady Ministrów. https://dsc.kprm.gov.pl/sites/default/files/pliki/ komunikacja_pisemna_0.pdf.

(KPR, Dowiat-Urbański, 2017) - Dowiat-Urbański, D. 2017. Szanowni Państwo! Departament Służby Cywilnej Kancelarii Prezesa Rady Ministrów, oprac. Komunikacja pisemna. Rekomendacje. Warszawa: Kancelaria Prezesa Rady Ministrów. https://dsc.kprm.gov.pl/sites/default/files/pliki/komunikacja_pisemna_0.pdf.

(KPR, Piekot, 2017) - Piekot, T. 2017. Prosta polszczyzna nowoczesnego urzędnika. 2017. Departament Stużby Cywilnej Kancelarii Prezesa Rady Ministrów, oprac. Komunikacja pisemna. Rekomendacje. Warszawa: Kancelaria Prezesa Rady Ministrów. https://dsc.kprm.gov.pl/sites/default/files/pliki/komunikacja_pisemna_0.pdf.

(SRJP 2010-201126) - Markowski A., Kołodziejek, E., Pisarek, W., WitaszekSamborska, M., Ignatowicz-Skowrońska, J., Kula, A., Szczaus, A., Sidorowicz, R., Skibski, K. i Zimny, R. 2012. Sprawozdanie ze stanu ochrony języka polskiego w latach 2010-2011. http://www.rjp.pan.pl.

(SRJP 2010-2011, Ignatowicz-Skowrońska) - Ignatowicz-Skowrońska, J. 2012. Sprawozdanie ze stanu ochrony języka polskiego w latach 2010-2011, ss. 55-111. http://www.rjp.pan.pl.

(SRJP 2010-2011, Kołodziejek) - Kołodziejek, E. 2012. Sprawozdanie ze stanu ochrony języka polskiego w latach 2010-2011, ss. 5-24. http://www. rjp.pan.pl.

(SRJP 2010-2011, Pisarek) - Pisarek, W. 2012. Działalność legislacyjna Sejmu i Senatu w latach 2007-2011 wobec wymagań ochrony języka polskiego. Sprawozdanie ze stanu ochrony języka polskiego w latach 2010-2011, ss. 25-31. http://www.rjp.pan.pl.

(SRJP 2010-2011, Szczaus) - Szczaus, A. 2012. Sprawozdanie ze stanu ochrony języka polskiego w latach 2010-2011, ss. 32-53. http://www.rjp.pan.pl.

26 SRJP 2010-2011 dotyczy poprawności językowej i sprawności komunikatywnej internetowych materiałów pisemnych, kierowanych do obywateli przez ministerstwa i wybrane instytucje centralne. Opracowanie to nie ma zaleceń, jak je cytować. 
(SRJP 2012-2013) - Rada Języka Polskiego przy Prezydium Polskiej Akademii Nauk. 2014. Sprawozdanie o stanie ochrony języka polskiego za lata 2012-2013. Język polski $w$ dokumentach używanych w obrocie konsumenckim. Ekspertyza. http://www.rjp.pan.pl.

(SRJP 2015-2016) - Dąbrowska, A., Majewska, A., Northeast, K., Jura, M., Rogoziński, Ł. i Zarzeczny, G. 2017. Sprawozdanie RJP za lata 2015-2016 - Promocja polszczyzny na stronach internetowych ambasad, konsulatów i Instytutów Polskich. http://www.rjp.pan.pl.

(SRJP 2016-2017) - Kłosińska, K., Zimny, R. i Żukiewicz, P. 2018. Sprawozdanie ze stanu ochrony języka polskiego za lata 2016-2017 - Język informacji politycznej. http://www.rjp.pan.pl.

(VT) - Vademecum tłumacza. Wskazówki redakcyjne dla ttumaczy. 2016. Luksemburg: Departament Języka Polskiego. Dyrekcja Generalna ds. Tłumaczeń Pisemnych. Komisja Europejska. https://ec.europa.eu/translation/ polish/guidelines/documents/styleguide_polish_dgt_pl.pdf.

\section{Netografia}

[191] 53.3. W wyrazach złożonych z liczbq lub literq $w$ pierwszej części. https://sjp.pwn.pl/zasady/W-wyrazach-zlozonych-z-liczba-lub-litera-w-pierwszej-czesci;629548.html (2.05.2019).

[73] 18.16. Pierwszy wyraz w jedno- $i$ wielowyrazowych tytułach. https://sjp. pwn.pl/zasady/73-18-16-Pierwszy-wyraz-w-jedno-i-wielowyrazowych-tytulach;629391.html (28.05.2020).

[85] 18.28. Nazwy urzędów jednoosobowych w aktach prawnych. https:// sjp.pwn.pl/zasady/Nazwy-urzedow-jednoosobowych-w-aktach-prawnych;629404.html (28.05.2020)

10.2. Użycie wielkiej i małej litery. W: Międzyinstytucjonalny przewodnik redakcyjny. https://publications.europa.eu/code/pl/pl-4100200.htm (31.05.2020)

Bogaty. https://synonim.net/synonim/bogaty\#g6778 (18.05.2020)

Hatalska, N. 2020. Mirrorworld, czyli pandemia vs infodemia. https://hatalska. com/2020/04/07/mirrorworld-czyli-pandemia-vs-infodemia/ (19.05.2020). Komunikat Ministra Nauki i Szkolnictwa Wyższego z dnia 5 listopada 2010 r. o ustanowieniu programu pod nazwą „Narodowy Program Rozwoju Humanistyki". M.P. $2010 \mathrm{nr} 86$ poz. 1014. (http://prawo.sejm.gov.pl/isap.nsf/ DocDetails.xsp?id=WMP20100861014 (28.05.2020).

Młodzieżowe słowo roku. https://sjp.pwn.pl/mlodziezowe-slowo-roku/Komentarze-jezykoznawcy;202300.html (24.05.2020). 
Piekot, T. 2017. Język 3 pach. https://www.youtube.com/watch?v=3H8lRpC75a0 (19.05.2020).

Rada Języka Polskiego i jej kompetencje. https://sip.lex.pl/akty-prawne/dzudziennik-ustaw/jezyk-polski-16854899/roz-3 (24.05.2020).

Rada Języka Polskiego. Sprawozdania o stanie ochrony języka polskiego. http://www.rjp.pan.pl/index.php?option=com_content\&view=article\&id=1835:sprawozdania-o-stanie-ochrony-jezyka-polskiego\&catid=$100 \&$ Itemid $=53(19.05 .2020)$.

Sprawozdanie ze stanu ochrony języka polskiego w latach 2010-2011. http:// www.rjp.pan.pl/images/Sprawozdania_o_stanie_ochrony_j\%C4\%99zyka/2010-2011.pdf(14.05.2020).

Użycie tacznika. [191] 53.3. W wyrazach złożonych z liczba lub litera w pierwszej cześci. https://sjp.pwn.pl/zasady/W-wyrazach-zlozonych-z-liczba-lub-litera-w-pierwszej-czesci;629548.html (2.05.2019).

Zaniedbany. https://synonim.net/synonim/zaniedbany\#g2176 (18.05.2020).

\section{A rich language, neglected language - some reflections upon the culture of language}

Abstract: The paper is related to selected linguistic phenomena. There is lexi-
cal, spelling, syntactic and punctuation negligence observed in communication,
which takes place in statements of state institutions. The analytical data derives,
among other sources from a report of the Council of Polish Language (recorded
between 2010 and 2011). The aim of the study is to indicate the reasons for the
selected mistakes and rules related to the correct spelling by presenting the proper
examples. The conclusions from the analysis of the official documents on language
culture are transferred into a reflection about the responsibility for the condition
of the Polish language, which is an important component of the national identity.

Keywords: culture of Polish language (syntax, lexis, spelling, punctuation, language mistakes), the condition of language, Council of Polish Language, report

Translated by Maria Stec 